\title{
Implementation of Library Policy i-Jakarta
}

\author{
Aditia $^{1}$, Retnowati Wahyuning Dyas Tuti ${ }^{2}$ \\ \{adietdki@gmail.com ${ }^{1}$, retnowatiwdtuti@yahoo.com ${ }^{2}$ \} \\ Universitas Muhammadiyah Jakarta, Indonesia ${ }^{1,2}$
}

\begin{abstract}
The library is one of the public facilities given by the Government to the public, but with its rapid advancement of the technology libraries that are normally to be reached directly by coming to the library as the government is making i-Jakarta library policy, with its people can access the books that are in the library just by using their smartphones. The purpose of this research is to know how the implementation of the general concern about the i-Jakarta library. This research uses the theory of Edward III. The study uses a descriptive method with a qualitative approach. Data collection is done by means of interviews, observations, and documentation. Data analysis uses the analysis model of Miles and Huberman, and tests the validity of the data using the triangulation. The results of this research are the policy implementation of the i-Jakarta library is still not running well, because the lack of socialization.
\end{abstract}

Keywords: Implementation, Policy, i-Jakarta.

\section{Introduction}

In the era of digitalization, the development of digital technology has brought about changes in lifestyles and the needs of the people, especially the people of Jakarta in accessing information. Digital technology is developing very rapidly beyond the speed of the times, as if everything changed in seconds because every time many new discoveries in the field of digital technology are directly implemented for the convenience of humans in interacting with one another [1][2]. The discovery and use of the Internet as the main media in the digital industry has changed the face of the world closer and easier so that the internet is becoming the primary need of people today which is increasingly fast, easy and inexpensive to meet the needs of public communication. The development of digital technology is supported by the presence of a computer that can be held in small fingers called a smartphone or smartphone that requires applications to accommodate daily activities in your hand [2][3]. All supporting applications have changed human habits in obtaining information that is fast, easier, closer and informative so that the need for digital content is very large to fill and update information such as digital books, music, data and others. The increasing use of social media has made system integrators compete in making applications that can accommodate the needs needed by the public.

Jakarta Provincial Government as the central government with a population of internet users should be able to be the drivers of the development of digital content to fill the void of public space so that the public gets interesting content to engage directly develop the infrastructure and public facilities in the digital realm with Work Unit (SKPD) is in charge of serving the public in the field of library and archives, namely the Jakarta Provincial Library and Archive Service (Dispusip) which has a vision: "The realization of a transparent and 
accountable information service to fulfill the information applicant's rights in accordance with the applicable laws and regulations and its mission, namely:

a) Improve management and information services that are of quality, correct and responsible.

b) Establish and develop a system of information provision and services.

c) Improve and develop competence and quality of Human Resources (HR) in the field of information services.

d) Realizing the disclosure of information on DKI Jakarta Provincial Government with a fast, precise, easy and simple process.

Meanwhile, according to Saleh and Kumalasari [4] the library is the heart or pulse for an agency/institution/university/other cooperative body. The library is no longer just a place to store and search for books, but more than that, which is a source/place to find information.

The condition of the people of a nation is a reflection of the level of culture and level of civilization that has been achieved, where the library is obliged to introduce the basics of science and skills to the community and instill an attitude to continuously learn continuously throughout life.

The DKI Jakarta Provincial Public Library as a place of service to the community to obtain information and study independently in order to improve its quality. As a center for information and science, the library does not only pay attention to physical facilities limited to buildings and printed books to meet the needs of its stakeholders. Quality and modern libraries have duties and functions to search, collect, organize, document and present information to users both in printed form and in electronic form so that customer satisfaction is achieved.

According to George Edward III in Santosa [5] there are 4 factors that influence the success or failure of policy implementation, including the factors (1) communication, (2) resources, (3) dispo side and (4) bureaucratic structure as follows:

a) Communication

According to Edward in Santosa [5] communication is defined as the process of delivering information from the communicator to the communicant. Information regarding public policy according to Edward III needs to be conveyed to the policy makers so that the policy actors can know what they have to prepare and do to carry out the policy so that the goals and objectives of the policy can be achieved as expected. According to Edward III policy communication has several dimensions, including dimensions of transmission (transmission), clarity (clarity) and consistency.

b) Resource

Resources have an important role in policy implementation. Resources consist of: human resources, budget resources, equipment resources and authority resources.

c) Disposition

That is the willingness, desire and tendency of the policy makers to carry out the policy seriously so that what is the goal of the policy can be realized.

d) Bureaucratic Structure

There are two main characteristics in bureaucratic structure, namely standard operational procedures and fragmentation. Standard operational procedures develop as an internal response to the limited time and resources of the implementers, as well as the desire for uniformity in the workings of complex and widespread organizations. 


\section{Methodology}

This study uses descriptive research with a qualitative approach and data collection techniques using the following techniques: interviews, observation, documentation and Focus Group Discussion. The informant selection technique uses a purposive sampling technique. Data analysis techniques used in this study refer to the concept of Miles \& Huberman [6], namely: Data reduction, data exposure, conclusion drawing and verification. While the data validity test uses triangulation.

\section{Results and Discussion}

Digital Library i-Jakarta, which is the pioneer of digital libraries in Indonesia, is one of the library services owned by the DKI Jakarta Provincial Library and Archives Service in collaboration with PT. Aksaramaya in developing digital based library services, which initially began in 2015, at that time the Governor of the Government DKI Jakarta Province, Mr. Basuki Tjahaya Purnama held a triathlon contest, in which the governor gave freedom for startup companies to cooperate with the DKI Jakarta provincial government through the Jakarta smart city in order to be able to contribute and innovate for the development of the Provincial Government of DKI Jakarta. One of the contributing vendors is PT. Woolu Aksaramaya with its i-Jakarta application. The purpose of holding this digital library is to improve the culture of public interest in reading by providing access to IT-based library services, a cooperation agreement No. 16 of 2016 [7] was made between the governor of DKI Jakarta and PT. Woolu Aksaramaya which was strengthened by the Regulation of the Governor of DKI Jakarta Province Government No. 2 of 2016 [8] concerning the i-Jakarta digital library. Collaboration with PT. Woolu Aksaramaya is still ongoing. PT. Woolu Aksaramaya provides electronic and provincial library applications. DKI Jakarta provides the contents of the electronic library in the form of electronic books. The DKI Jakarta Provincial Government obtains Use Rights for the application while the Copyright/Property Rights remain at PT. Woolu Aksaramaya.

In the Implementation of i-Jakarta Library Policy according to the indicators of Edward III are as follows:

a) Communication

In terms of communication, which means how information is conveyed from the communicator to the communicant, the policy of the i-Jakarta library has previously followed the development of existing technology, the library which was previously only accessible by coming directly to the library and reading or borrowing books or directly, then with the library i-Jakarta, especially the people of DKI Jakarta, can access libraries and read books contained in the i-Jakarta application through their smartphones, and the delivery of information between policy makers to policy implementers and from policy implementers to the public is still not going well and optimally. because there are still many people who still do not know about the iJakarta application itself, it still needs a comprehensive socialization to the people of DKI Jakarta, to maximize communication between policy implementers to the objectives to be achieved.

b) Resource

In terms of resources has an important role in the implementation of policies related to human resources, budget resources, and equipment resources, and i-Jakarta 
library policies, there are various resources such as human resources, budgets and equipment. In supporting the implementation of i-Jakarta digital libraries, the DKI Jakarta Province Dispusip has facilities, infrastructure and resources that support the implementation of i-Jakarta digital library services.

The number of Human Resources who have responsibilities in accordance with the position and class previously described in the Library and Archives Service is 108 people consisting of 1 Echelon II Officer, 6 Echelon III Officials, 18 Echelon IV Officials, 21 official's functional archivist and functional official; and 63 general functional staff members. While the number of employees of the Library and Archives Service along with its sudin's a total of 226 employees. In addition to resources owned. Dispusip also has the facilities and infrastructure assets used for the implementation of digital library services i-Jakarta such as computers, cabinets, sofas etc.

c) Disposition

As "the will, desire and inclination of policy makers to carry out the policy seriously so that what the policy objectives can be realized". The willingness and desire of the implementers of the policies towards the existing policies is sufficient to influence the running of the policy well or not, therefore besides the obligations that are actually owned by the implementers of the policy, the disposition indicator has the name of an incentive. it is hoped that the attention of the will in the implementation of the policy will be higher by adding incentive money to the implementers of the policy to encourage the implementers to carry out orders properly.

d) Bureaucratic Structure

Bureaucratic structures are characteristics, norms, and patterns of relationships that occur repeatedly in executive bodies that have both potential and tangible relationships with what they have in carrying out policies. In this case it can be seen that the relationship between characteristics, norms, norms and patterns between policy makers and policy implementers has been running optimally, but still needs improvement in relations to the community.

\section{Conclusion}

From a number of discussions based on the four indicators it can be concluded that, the implementation of the i-Jakarta library policy has been running optimally and well, it can be seen from the delivery of information that goes well to the targets to be addressed in the policy. In the provision of facilities and infrastructure is quite good, because all can be fulfilled.

\subsection{Suggestion}

Although the delivery of information has been running optimally and well, but the delivery of information must continue, because it is undeniable that there are still people who still cannot use how to operate the i-Jakarta, moreover there are still many people who still do not have smartphones with it for those who do not yet have a smartphone they cannot use the application, because it is based on an application that can only be downloaded via the AppStore or PlayStore. 


\section{References}

[1] Y. Ioannidis et al., "Digital library information-technology infrastructures," Int. J. Digit. Libr., vol. 5, no. 4, pp. 266-274, 2005.

[2] P. Lyman, "What is a digital library? Technology, intellectual property, and the public interest," in Books, Bricks and Bytes, Routledge, 2017, pp. 1-34.

[3] I. H. Witten, D. Bainbridge, and D. M. Nichols, How to build a digital library. Morgan Kaufmann, 2009.

[4] A. R. Saleh, "Manajemen perpustakaan,” 2014.

[5] B. G. Santosa, "Implementasi Program Penataan Administrasi Kependudukan Di Kabupaten Madiun," J. Adm. Publik, vol. 4, no. 4, 2016.

[6] M. B. Miles, A. M. Huberman, M. A. Huberman, and M. Huberman, Qualitative data analysis: An expanded sourcebook. sage, 1994.

[7] Pemerintah DKI Jakarta, Cooperation Agreement Number 16 of 2016 Concerning the i-Jakarta Digital Library. 2016.

[8] Governor of DKI Jakarta Provincial, Government Regulation Number 2 of 2016 Concerning the i-Jakarta Digital Library. 2016. 